\title{
A Neglected (But Challenging) Archaeological Perspective
}

\author{
Bert Olivier* \\ Department of Philosophy, University of the Free State, South Africa
}

Submission: December 04, 2017; Published: April 04, 2018

*Corresponding author: Bert Olivier, Department of Philosophy, University of the Free State, South Africa, Email: OlivierG1@ufs.ac.za

\section{Commentary}

In the world of archaeology it seems that it takes a long time for what Thomas Kuhn called a "paradigm switch" to take place. By this phrase - as is well-known - Kuhn [1] meant a sudden abandonment of a certain fundamental conception of a science, which has held sway for some time, in favour of another, at a point when the evidence for a new fundamental approach, and hence for abandoning the old one, has become overwhelming. This, according to him, is the "structure" of a "scientific revolution", and it is my distinct impression that such a scientific revolution has not yet taken place in archaeology. My reasons for saying this are as follows.

It is safe to say that the conventional, or orthodox, assumption in archaeology, encountered in the vast majority of textbooks, and underpinning the bulk of ongoing archaeological research, amounts to the view that the earliest 'advanced' civilisation on Earth was that of ancient Egypt, which flourished approximately 3500 years BCE. As a corollary of this view it is accepted that before $10000 \mathrm{BCE}$ - more or less when the agricultural revolution is supposed to have occurred - humans on the planet lived in small communities of hunter-gatherers, and were certainly not capable of 'advanced' cultural activities such as building structures evincing thorough knowledge of sophisticated, mathematically-informed building techniques. Part of the reason for adhering to this conventional view - and leaving aside the question of suitable criteria for civilisation advancement is the arguably narcissistic belief that contemporary society instantiates the most advanced technological society in the history of humankind. This goes hand in hand with the view, that there was a gradual development from about 10000 years ago, through ancient Egyptian culture (and others such as ancient Greek and Persian cultures), as well as early and late modern civilisation, to where humanity is today, namely (supposedly) at the zenith of technically developed and oriented civilisation.

Yet, as long ago as 1995 someone called Graham Hancock published an extensively researched book, Fingerprints of the Gods, the multiple references in which alone should convince one of the thoroughness of the research. In the book Hancock put forward the argument that, contrary to the mainstream archaeological assumption, that there were no advanced civilisations on Earth before the ancient Egyptians, archaeological evidence suggests that such civilisation(s) did exist before 12500 years ago. He also discusses the hypothesis suggested by the large number of 'deluge' myths [2] in different cultures - that this civilisation suffered a catastrophic episode (probably when a comet struck the earth), subsequent to which its survivors scattered across the planet, settling in various locales.

The first question that these claims poses is, of course particularly to people who have not read Hancock's work - what is the evidence for the existence of such ancient civilisations? In Fingerprints of the Gods evidence revolves, inter alia, around indications that knowledge of the coastline of part of Antarctica - today covered in an (admittedly melting) ice sheet - existed prior to the modern discovery of Antarctica, indicated by the socalled Piri Reis map dating from 1513, which Reis acknowledged as resting on maps of much older provenance. The appearance of the map (which showed the coastline beneath the ice) suggested something far more astounding, however: that it rested on cartographic evidence dating back to a time before ice covered Antarctica's land mass - something that led cartologist Charles Hapgood to claim that "irrefutable evidence" existed, pointing to the fact that "the earth had been comprehensively mapped before $4000 \mathrm{BC}$ by a hitherto unknown and undiscovered civilization which had achieved a high level of technological advancement". Relevant evidence also involves the mechanism of "earth-crustdisplacement", according to which the entire 'lithosphere' of the earth (the outer crust or 'skin') may shift in its entirety, displacing surface areas in significant ways. The upshot of this is that Antarctica had probably been subject to such earth-crustdisplacement, and had previously probably been much warmer than today, because it was located approximately 2000 miles further north than at present, where an ancient civilisation possibly existed millennia ago.

For the archaeology establishment the evidence for Hancock's claims was too thin, and amounted to 'bad (or fringe) archaeology'. His later book, Magicians of the Gods, 
on the other hand, compensates for this perceived dearth of evidence by providing instances of such in the domain of orthodox archaeology, the most important of which is Göbekli Tepe in Turkey [3] where megalithic structures, clearly based on sophisticated construction-knowledge, have been discovered. Furthermore, these have been recognised as being as old as 11,600 years (at least) by mainstream archaeologists, using orthodox techniques of dating. Another site testifying in the same way to the out datedness of the dominant archaeological paradigm is Gunning Padang in Indonesia [3], which, like Göbekli Tepe, constitutes an example of the kind of building that reflects knowledge not compatible with the supposed exclusive existence of hunter-gatherer communities before $10000 \mathrm{BCE}$; instead, it embodies advanced architectural and engineering knowledge, and, to add insult to injury for the mainstream archaeology establishment, members of the latter community themselves have dated it as being as old as (if not older than) 12,500 years.

Importantly, Hancock reminds one that the members of a postapocalyptic diaspora (referred to earlier) would have possessed the knowledge that had enabled them to build the civilisation destroyed in the hypothesised cataclysm - knowledge they could, and did, use elsewhere to build 'megalithic' edifices witnessing to such cultural knowledge, including mathematics, engineering, architecture, sculpture and art. If some of these structures are indeed as old as 12500 years, they would significantly antedate the putatively 'oldest' civilisation, that of the ancient Egyptians. And there have been signs that the archaeological community may have to change its stance regarding the standard notion of civilizational history, such as the article by Andrew Curry [4], and that by Charles Mann in National Geographic [5], both of which were published even before Hancock's Magicians of the Gods [3]. Whether or not that will lead to the long-overdue scientific paradigm switch in archaeology or not remains to be seen [6].

\section{References}

1. Kuhn T (1962) The Structure of Scientific Revolutions. Chicago: The University of Chicago Press.

2. Hancock G (1995) Fingerprints of the Gods. London: William Heinemann Ltd.

3. Hancock G (2015) Magicians of the Gods. The Forgotten Wisdom of Earth's lost Civilisation. London: Coronet; Hodder and Stoughton.

4. Curry A (2008) Gobekli Tepe - The world's first temple? Smithsonian Magazine.

5. Mann CC (2011) Göbekli Tepe - The birth of religion. National Geographic.

6. http://cryptoanthropologist.blogspot.co.za/2016/03/8-mysteriousfacts-about-gunung-padang.html

\section{Your next submission with Juniper Publishers will reach you the below assets}

- Quality Editorial service

- Swift Peer Review

- Reprints availability

- E-prints Service

- Manuscript Podcast for convenient understanding

- Global attainment for your research

- Manuscript accessibility in different formats

( Pdf, E-pub, Full Text, Audio)

- Unceasing customer service

Track the below URL for one-step submission https://juniperpublishers.com/online-submission.php 